\title{
An Off-site construction Readiness Maturity Model for the Indian Construction Sector
}

\author{
Abstract \\ Purpose \\ This paper presents an Off-Site Construction (OSC) readiness maturity model for assessing the \\ readiness of off-site construction in the Indian construction sector.
}

\section{Design/Methodology/Approach}

The research was conducted in three stages. The first stage consisted of a detailed literature review to document 17 different variables affecting the OSC adoption in India. In stage two, 15 semi-structured interviews were carried out where the participants were asked to refine those variables for the Indian context and define what would be different levels of attainment. In the third stage, another set of 5 semi-structure interviews was performed to validate the maturity levels and definitions.

\section{Findings}

A three-level OSC readiness maturity model is presented for discussion. This describes 17 variables at different levels of maturity.

\section{Practical Implications}

The proposed OSC readiness maturity model guides construction practitioners in India through a structured process to enable them to assess their OSC readiness in the market. This assessment enables them to evaluate and benchmark their processes through the strategic and operational phases. The maturity model also identifies the areas of concern and the scope for further development or change to secure the optimal advantage of OSC methods.

\section{Originality/Value}

The research produced a model to assess the readiness of off-site construction adoption in the Indian construction sector. Although the model has been applied to the Indian construction sector, it can easily be modified to accommodate other OSM contexts.

\section{Keywords}

Off-site Construction, Construction Industry, Housing, Modular Construction, Indian Construction. 


\section{Introduction}

India is the second most populated country in the world, with 1.31 billion people (WorldBank, 2020). India's construction industry is driven mainly by the Government of India's investments on core infrastructure projects and the creation of urban infrastructure (Maniar, 2010; Nallathiga et al., 2018); where for example India is expected to accommodate six megacities with a population of above ten million by 2030 (NITI Aayog, 2018). This growth has been supported by ongoing economic development, industrialisation, and urbanisation (Gupta et al., 2009; Kumar, 2019). Given this growth and demand, there is an urgent need to examine alternative forms of construction, such as modular and hybrid forms of OSC. In this respect, approaches such as these have demonstrated significant advantages, from time and cost savings, through to lower levels of environmental impact, reduced reliance of on-site skilled labour, improved safety performance and higher quality end products (Blismas and Wakefield, 2009; Goulding et al., 2012; Jin et al., 2020; Wasim et al., 2020).

Notwithstanding these benefits, Goulding et al. (2015) highlighted the need to develop evidenced-based OSC business process models and strategies to promote wider uptake. While some studies demonstrated the importance of strategy, Blismas et al. (2006) revealed that the evaluation of the degree of industrialisation of a component or building system production in off-site construction needed attention. Additionally, Smith and Narayanamurthy (2008) stressed the need to investigate an appropriate prefabricated building system to fulfil the Indian housing shortage. Given these challenges, it is important to critically reflect on the broader potential of OSC, from inception, through to planning and project execution (Kamar et al., 2009; Smith and Narayanamurthy, 2008), as in many countries, the decision to use OSC methods have been based on 'anecdotal evidence rather than rigorous data' (Pasquire and Gibb, 2002).

More recently, however, whilst many Indian construction organisations have taken an interest in OSC, their general lack of awareness has seemingly discouraged intensive implementation (Wuni et al., 2020). In this respect, organisational confidence seems to be a contributory factor, especially concerning the integration of existing construction practices to deliver OSC capabilities (Arif et al., 2012; El-Abidi et al., 2019). This situation is compounded by a general lack of resources to facilitate the OSC transition to satisfy market demand (Goodier and Gibb, 2007; Edialeyoung et al., 2020). This is a significant gap in the literature, which this paper aims to address. Specifically, an appropriate tool for measuring Indian construction organisations' level of maturity and readiness to adopt OSC. In this respect, OSC readiness is defined as 'a measure of the degree to which an organisation is ready, prepared, or willing to obtain benefits from OSC practices'. This paper presents an OSC readiness maturity model for discussion. This investigates the extent to which organisations are ready to adopt OSC technologies in Indian construction organisations.

This paper is divided into the following five sections: Literature Review; Research Methodology; Research Findings; Discussion; and Conclusion. 


\section{Literature Review}

Off-Site Construction (OSC) is a different approach to traditional construction methods. OSC can be understood as the manufacturing and prefabrication of building components and systems assembly away from the site, perhaps in off-Site locations (Gibb, 2001; Pan et al., 2007; Arif and Egbu, 2010). Given the need to examine the extent to which Indian construction organisations were ready to adopt OSC technologies, the initial intrinsic vision was to investigate the significant factors that influenced (or were perceived to control) the OSC decision-making process over traditional methods, especially in India (Yang, et al., 2007; Arif et al., 2012). This requirement naturally included the inherent 'negative challenges' that have historically influenced OSC adoption and uptake - the findings of which have been reported extensively in the literature (Nadim and Goulding, 2011; Arif et al., 2012 ${ }^{\mathrm{a}}$; Mao et al., 2015). Where, for example, new approaches can sometimes be seen as being risky as opposed to traditional ways of thinking (BRE, 2001; BURA, 2005; CRC, 2007; Rahman, 2013). OSC is relatively new in India. This may be due to several reasons, including higher taxes (Bendi et al., 2020; Mao et al., 2015; Rahman, 2013). Capital cost is considered a critical factor when considering OSC, as higher costs are often seen as a major barrier in the selection process; where some studies have indicated that OSC can be more expensive than traditional methods (Goodier and Gibb, 2005; Razkenari et al., 2020). However, a corollary to this is that OSC can often improve cost certainty - which is seen as a prerequisite for clients and contractors (Antoine et al., 2018; Hartmann and Hietbrink, 2013; Jaillon and Poon, 2010; Xiao and Proverbs, 2003). The paucity of relevant information and guidance on OSC is also seen as a barrier to uptake (Goodier and Gibb, 2005; Kamar et al., 2009; CITB, 2017); which includes everything from logistics, through skills availability, manufacturing capacity, supply chains and the transportation infrastructure (Bekdik et al., 2018; Bendi et al., 2020; Innovate Off-site, 2010; Rahman, 2013).

Readiness models have been used in various industries to assess the readiness and status of an organisation before introducing any new technology (Khalfan et al., 2001). For example, COMPREST (Cost Model for Pre-assembly and Standardization) investigated the standardisation, pre-assembly design and construction processes within the Mechanical Services sector (Aldridge et al., 2001; Ayinla et al., 2019). RACE (Readiness Assessment for Concurrent Engineering) has been widely used in the software engineering, automotive and electronic industries (Karningsih et al., 2015), where Khalfan et al., (2001) found that this could be modified for use in the construction sector. PMO (Process Model of Organisation) and PMO-RACE are models that have been used for analysing and designing processes to identify problem areas and performance improvements (Wognum et al., 1996).

Within the construction sector, SPICE (Standardised Process Improvement for Construction Enterprises) has been used to document and assesses critical construction processes within an organisation (Finnemore and Sarshar, 2000). Similarly, the Project Management Process Maturity (PM)2 Model can be used as a reference point for applying project management practices and processes (Kwak and Ibbs, 2002). Other approaches include the Interactive Method for Measuring Pre-assembly and Standardisation (IMMPREST, 2007), and Benchmarking and Readiness Assessment for Concurrent Engineering in Construction 
(BEACON) Model (Khalfan et al., 2001) to assess Concurrent Engineering readiness in the construction industry.

One of the major initiatives used to assess organisational capability was the development of the Capability Maturity Model (CMM) at Carnegie Mellon University (Paulk et al., 1993). This approach focussed on excellence-driven through process maturity levels, where each process maturity level “...provides progressively stronger foundations for higher evolutionary stages of process maturity” (Hinks et al., 1997). The CMM method demonstrates how capable an organisation was at achieving continuous improvement. This assessment is undertaken over five main levels: Level 1 "Initial”, Level 2 "Repeatable", Level 3 "Defined", Level 4 "Managed” and Level 5 “Optimising”. Where Level 1 maturity typically represents low levels of maturity, demonstrated by unstructured or ad hoc systems/processes/practices; whereas, Level 5 represents the highest level of maturity - evidenced by fully streamlined and optimised systems/processes/practices. The concepts of this approach are based on the notion that distinctions can be made in the levels of maturity of organisations based on pre-set criteria. Criteria can include a number of fields, including process maturity; project maturity; management maturity; cultural maturity; organisational maturity; technological maturity etc. This type of assessment can also be used as a benchmarking exercise as part of competitor analysis and market orientation, including construction (Hinks et al., 1997; Sarshar et al., 2000; Goulding and Alshawi, 2002; Davis and Walker, 2009; Eadie et al., 2011; Perera and Rodrigo, 2017).

Goulding and Arif (2013) presented a number of variables that influenced OSC adoption in China, India, Japan, the U.K., Malaysia, and North America. From this, Bendi et al. (2020) used some of these variables to discover additional insight, with specific variables that impacted OSC implementation within Indian organisations. This research identified 26 variables, which, after factor analysis, was reduced to 17. Principal Component Analysis was conducted by forcing the number of factors to 4 using the maximum likelihood method with varimax rotation technique. The process was initiated by listing the key factors (F1: Operational Challenges; F2: Strategy; F3: Planning Certainty; and F4: Operational Impact) mapped against the respective components, critical factors and associated definitions (Figure 1). 


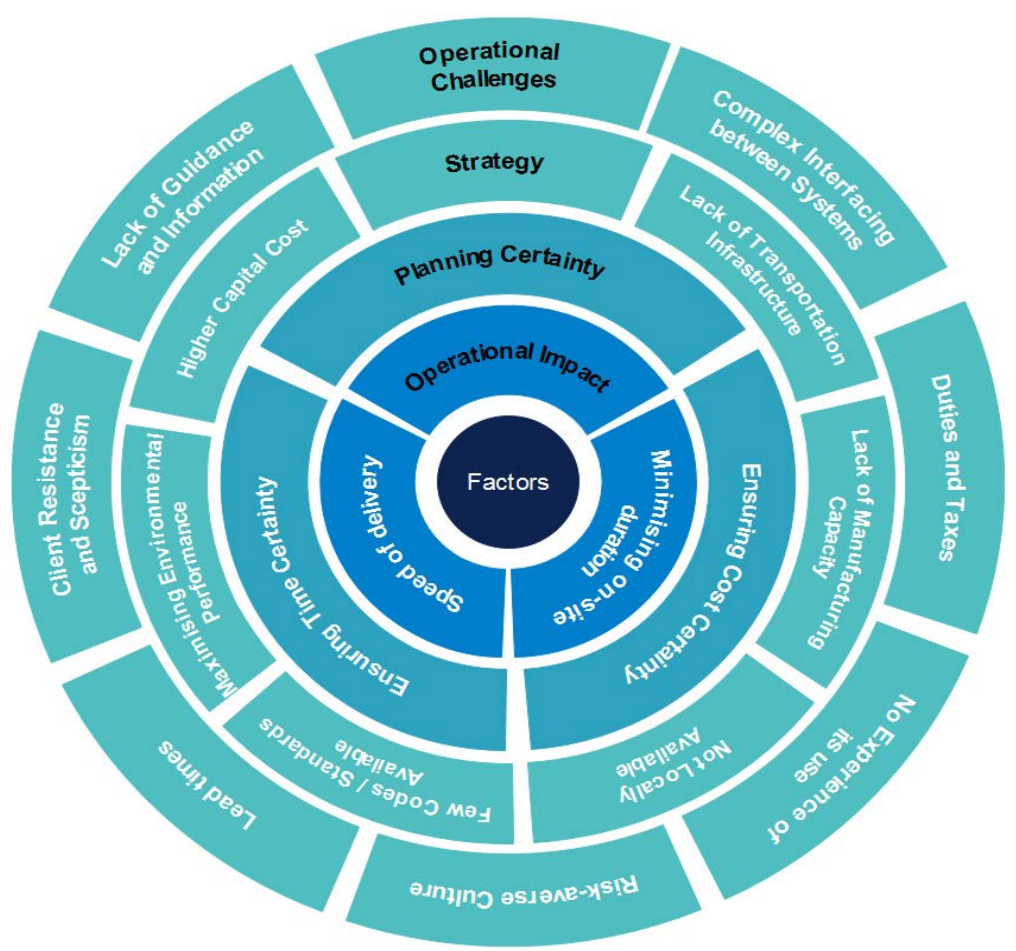

Figure 1 Factor Analysis Variables and Four Groups (Bendi et al., 2020)

The four key factors presented in Figure 1 presents a viable trajectory for future uptake. However, Bendi et al. (2020) present these variables in isolation. Other work on OSC examined the important aspects of People, Process and Technology (Nadim and Goulding, 2010; Goulding et al., 2012), including OSC roadmaps (Goulding and Arif, 2013; Bowmaster and Rankin, 2019), Platform, Process and Product integration platforms (Blismas and Wakefield, 2008), OSC Future Landscapes (Oughton, 2016). Whilst all these attempts provide fertile points for discussion and further development, the main challenge still remains - how do organisations actually prepare themselves for this transition to OSC? This needs to be addressed at the organisational level, where it is proffered OSC uptake actually takes place. This is where the level of 'readiness' and organisational maturity is so important.

Acknowledging the above challenges and opportunities, the point of departure of this research adopted a research lens which purposefully aimed to integrate the core concepts of CMM matched to the needs of construction organisations in India wishing to adopt or embark on a transition to OSC. In doing so, it uses the variables developed by Bendi et al., (2020) as a starting trajectory to develop the rubrics needed to develop an Offsite Construction Readiness Maturity Model for the Indian market.

\section{Research Methodology}

This research was conducted through three sequential stages, where the findings from each help shape and inform proceeding stages. Given that organisations tend to embrace social systems (Rogers, 2010), the philosophical stance of this work aimed to determine the factors and mechanisms that typically affect organisational behaviour (ergo transition to OSC). The underlying assumption here was that the Indian construction context could be observed and that social reality (within this context) was constructed by the subjective meaning of actors 
within this environment. This aligns to the notion that experiences are predominantly formed through interaction with individuals, and through the absorption of organisational context and cultural norms (Creswell, 2007). On this basis, from a philosophical worldview perspective, this paper embraces interpretivism as the main lens for discovery. The challenge is to capture constructs that reflected actors' perception, experience and understanding of 'objective reality' (Miles et al., 2013; Fellows and Liu, 2015; Bryman and Bell, 2015; Holt and Goulding, 2017). The approach adopted was therefore predominantly qualitative by nature (as the underlying challenge was to invite critique into the causal drivers and barriers to OSC implementation). Recognition was also made on the value of capturing tacit and explicit knowledge from relatively small sample sets (Hyde, 2000).

The first stage of this research involved a critical analysis of maturity models and frameworks, including cognate and non-cognate disciplines. This process aimed to capture the types of models and variables required to meet the Indian context. In this respect, the variables from Bendi et al. (2020) were used as a starting point for further development, supported by several variables from similar research. Readiness and capability maturity models designed for the construction sector were also considered in this first stage. Stage two engaged 15 semistructured interviews using purposive sampling (Table 1). This process aimed to refine these variables for the Indian context. This also aimed to define the attainment levels for each level of maturity using "low", "medium” and "high" demarcations. From this, the contextualised Indian definitions and levels of maturity were established. The semi-structured interview approach allowed much greater flexibility of response through conversational dialogue (Fergusson and Langford, 2006). The third and final stage of this process engaged 5 semistructured interviews with senior construction staff (Table 2). We purposefully secured participants who were working in companies that had nationwide operations in India, and due to their senior positions and experience, they were also aware of the regional drivers/barriers as well. This approach was used to provide additional surety on the findings secured from stage two. It also acted as a validation measure to confirm the maturity levels and associated definitions. From this, the definitions of variables and attainment levels were established, including how the factors could be measured across the three levels.

Table 1. Respondent Classification and Experience

\begin{tabular}{l|cccccc|}
\multicolumn{7}{c}{ Experience (Years) } \\
\hline Job Role & $\mathbf{6 - 1 0}$ & $\mathbf{1 1 - 1 5}$ & $\mathbf{1 6 - 2 0}$ & $\mathbf{2 1 +}$ & Total & Percentage \\
Manufacturers/Suppliers & 1 & 1 & - & - & 2 & $\mathbf{1 3 . 3 \%}$ \\
Contractors & - & 1 & 1 & - & 2 & $\mathbf{1 3 . 3 \%}$ \\
Engineer & - & 3 & 2 & - & $\mathbf{5}$ & $\mathbf{3 3 . 3 \%}$ \\
Architects & - & 2 & 1 & - & $\mathbf{3}$ & $\mathbf{2 0 \%}$ \\
Policy Makers & - & 1 & 1 & 1 & $\mathbf{3}$ & $\mathbf{2 0 \%}$ \\
& & & & & $\mathbf{1 5}$ & $\mathbf{1 0 0 \%}$ \\
\hline
\end{tabular}


This represented six middle-level managers (40\%), five senior managers (33.3\%), and four directors (26.6\%) positions, with an aggregate industry experience level of $15+$ years' experience of working in OSC. The duration of each interview ranged from 60 to 90 minutes to answer five essential questions.

Question one aimed to investigate the factor groups needed for the development of the OSC readiness maturity model, where respondents were asked to evaluate the content and classification of these factors. All 15 respondents agreed with the current classification of factors presented. Question two considered the scope and definitions needed for each sub-factor of the OSC readiness maturity model. However, two (out of 15) participants disagreed with the scope of the sub-factor 'Duties and taxes', which was subsequently restructured and agreed by all. Question three covered the content of each of the maturity levels. Question four covered the adequacy of the number of levels and their appropriateness for assessing the OSC readiness of construction organisations in India. This invited respondents to suggest alternative levels, as typical CMM approaches often follow a five-level approach. From this question, four respondents challenged the applicability of five levels, noting their preference for three. The remaining respondents reflected on this change and agreed that three levels were more appropriate to their needs as OSC in India was still in its infancy. Finally, question five dealt with the responsiveness and applicability of this maturity model for incorporation within the Indian construction sector. All 15 respondents highlighted the need for this model, noting that this would help them gauge their transition and organisational readiness to move from traditional approaches to those reflecting the OSC philosophy. In summary, therefore, three levels of maturity were adopted in this OSC readiness model. Where: Level one indicates organisations that partly follow the critical steps involved in the effective implementation of OSC techniques; Level two provides indicators for standardisation and optimal implementation of OSC techniques, and Level three incorporates clear operational procedures and organisational learning best practice.

The third and final stage of this work engaged the services of an additional set of domain experts to challenge and refine the results obtained from stages one and two. In this respect, five new independent domain experts from the OSC community (not previously associated with the original respondents used in stage two) were chosen to engage with this final refinement stage; in particular, to validate the maturity levels and definitions - see Table 2.

Table 2. Management Classification and Experience

Experience (Years)

\begin{tabular}{l|cccc|c|}
\hline Management Level & $\mathbf{6 - 1 0}$ & $\mathbf{1 1 - 1 5}$ & $\mathbf{1 6 - 2 0}$ & $\mathbf{2 1 +}$ & Total \\
Senior Management & - & 1 & 2 & 2 & 5 \\
\cline { 1 - 1 } & - & 1 & 2 & 2 & $\mathbf{5}$ \\
\hline
\end{tabular}


Table 2 presents the management classification and experience of five domain experts in OSC. These were purposively selected based on their direct engagement with OSC. Respondent backgrounds included two architects, two suppliers, and one engineer; with an aggregate industry experience level of 19+ years' experience of working in OSC. A series of semistructured interviews were conducted ranging from 60 to 90 minutes to validate the maturity levels and definitions. The definitions of variables were also refined to indicate how they could be measured.

The overall approach adopted for this paper is qualitative. This was adopted to achieve an indepth assessment of each variable and maturity level of the model. The qualitative methods are usually concerned with words instead of numbers (Bryman \& Bell, 2015). Its findings acknowledge the qualities of a phenomenon rather than its mathematical measurements. Qualitative methods also cover the historical aspect of a subject holistically leading to the production of a wealth of advanced data on a small sample (Kenneth, 2000). This research adopted the ontological position of "subjectivism" as the current research attempted to observe the current practices, perceptions, and consequent actions of other social factors such as awareness and people's perception. It required identification of factors, conceptualising and validating the OSC readiness maturity model. These research activities involved the study of expert views and observation of events and processes of organisations which have led the research to take interpretivism in terms of epistemological position.

\section{Research Findings}

Previous work by Bendi et al. (2020) identified and shortlisted the factors affecting the uptake of OSC in India using factor analysis. These results were adopted in the development of this maturity model to take it further. The results from the semi-structured interviews undertaken in stage two helped establish the maturity model constructs and OSC readiness indicators for the Indian context. This phase also examined the maturity levels to i) validate the data collected from the literature review, and ii) understand the challenges, barriers, and drivers of OSC. The questions were designed specifically to gain a deeper understanding of the impact of these variables. From this, four key factors and associated were established (Table 3). 
Table 3. Key Factors and Associated Variables

\begin{tabular}{l|l}
\hline Key Factors & Variables \\
\hline Factor 1: Operational & Complex interface between systems \\
Challenges & Duties and Taxes \\
& Lack of experience \\
& Risk-averse culture \\
& Lead times \\
& Client resistance and scepticism \\
& Lack of guidance and information \\
\hline Factor 2: Broad Execution & Lack of transportation infrastructure \\
Strategy & Manufacturing capacity \\
& Local availability \\
& Availability of codes/standards \\
& Maximising environmental impact gains \\
& Capital cost \\
\hline Factor 3: Planning & Cost certainty \\
Certainty & Time certainty \\
\hline Factor 4: Operational & Minimising on-site duration \\
Efficiency & Speed of delivery \\
\hline
\end{tabular}

Table 3 presents the main findings from stage two. These were collated, analysed and categorised using discourse analysis and actor verification. A synopsis of the results from these 17 variables is presented as follows.

\section{Complex interface between systems}

Respondents agreed that complex interfacing issues were a challenging but essential issue. These could be easily be managed if carefully thought through. However, the fragmented nature of the construction industry can sometimes make it harder to standardise designs for OSC. Special emphasis is needed from the outset.

\section{Duties and Taxes}

Various custom and excise duties can be levied on OSC systems imported from other countries. Respondents observed that OSC in India was still in its infancy and that some parts/module/systems have to be imported from other countries (which incur duties and taxes). This discourages OSC uptake in favour of adopting traditional construction methods instead.

\section{Lack of experience}

Skills shortages seem to be a global challenge. However, as OSC is a relatively new domain in India, respondents observed that this should be high on the agenda, especially as OSC predominantly requires a highly skilled workforce for both products and processes. 


\section{Risk-averse culture}

Given the perceived historical 'negative' image of OSC, respondents noted that this needed to be acknowledged and addressed. In particular, three respondents observed that this was intrinsically linked to existing cultural norms and perceptions, where departure from traditional ways of thinking could be seen as being 'risky'. This was further supported by the need to absorb underpinning logic and business rationale over time.

\section{Lead times}

All respondents commented on the importance of evaluating the potential impact of lead times of OSC. This was seen as a significant barrier. Three respondents believed the factors affecting this issue concerned a lack of guidance, experience and knowledge of manufacturing capacity. This was compounded when evaluating complex interfaces between modular systems with different lead times.

\section{Client resistance and scepticism}

All respondents agreed that this factor severely hindered OSC uptake and associated innovation opportunities. This was seen as a particular challenge in new markets such as India. That being said, over half of the respondents believed that things were gradually changing, especially with the introduction of innovative, vertically integrated off-site manufacturing (OSM) factorydriven solutions entering the market.

\section{Lack of guidance and information}

Whilst OSC was still considered to be a relatively new trend, and participants observed that there needed to be some form of standardised codes of practice and regulations to support it. All respondents reported a general lack of OSC guidance and information within India. Two respondents, in particular, thought that this was a significant barrier to OSC adoption.

\section{Lack of transportation infrastructure}

It was acknowledged that OSC is particularly reliant on appropriate transportation infrastructure. Where, for example, 14 respondents believed that the geographical displacement of parts, limited on-site space and site-access issues seriously affected the viability of OSC adoption. Moreover, one respondent added that this was also hindered by the limited number of manufacturers in India.

\section{Manufacturing capacity}

The majority of respondents commented on the advantages of OSC, not least, the impact of manufacturing. This was considered a significant advantage due to its effect on the overall quality and speed of delivery compared to traditional approaches. However, two respondents raised the issue of high initial set-up costs associated with OSC, and difficulty in maintaining consistent demand throughput to meet assembly line production methods/requirements.

\section{Local availability}

All respondents agreed that limited local availability could impinge on the decision to adopt OSC, as the proximity of services and goods often influenced project viability. This was exacerbated in remote areas where parts and modules may not be readily accessible. 


\section{Availability of codes/standards}

All respondents commented that this variable was closely linked with the lack of guidance available. The core challenge observed was not just the availability of codes/standards per se, (apropos explicit and tacit knowledge), rather the explicit knowledge published by regulatory authorities, as lack of approved design standards prevented uptake.

\section{Maximising environmental impact gains}

All respondents highlighted that OSC could help reduce the environmental impact - from carbon footprint, through to reduced waste and resource requirements. However, they also observed that the environmental impact of construction activity needed to be carefully controlled, from landfill through to transportation.

\section{Capital cost}

Respondents noted that capital cost was often the predominant factor in the construction decision process. Three respondents mentioned the need to absorb higher up-front costs associated with OSC, particularly at the beginning of a project. However, they believed that once this initial investment had been integrated into organisational business models, several opportunities could be leveraged through economies of scale.

\section{Cost certainty}

One of the major challenges of securing projects is the certainty to which costs can be predicted and controlled. More often than not, this is seen as a fundamental prerequisite for both contractors and clients where fixity and reliability are essential. All respondents agreed that whilst OSC could bring cost certainty, but that this was also reliant on other related factors associated with production and supply chain dependencies.

\section{Time certainty}

All respondents agreed that time certainty was equally of high importance to decision-makers, especially construction clients. Three respondents noted that time certainty with OSC was significantly improved (compared to traditional methods) due in part to early design fixity. However, this was counterbalanced by an inability to make late design changes.

\section{Minimising on-site duration}

Respondents commented that the use of OSC could reduce the amount of time spent on site due to the pre-manufacturing process, and was particularly useful during inclement weather where traditional approaches were often hindered. All respondents agreed that OSC projects could be delivered quicker than traditional methods when supported by rich production data.

\section{Speed of delivery}

All respondents agreed that OSC methods were significantly faster (from a delivery perspective) than conventional construction methods and that this was a key driver and advantage for OSC adoption in India. Two respondents provided a caveat to this, as delivery was also connected to the local availability of goods and appropriate infrastructure. 
In summary, these 17 variables helped reinforce the core content of the OSC readiness maturity model. Stage two of this research confirmed the need to incorporate these variables into the model for further development. It was observed that respondents' were fully aware of these issues and suggested that companies should actively embrace these as part of their delivery solutions. The next stage of this work involved developing the OSC readiness maturity model, with the five domain experts highlighted earlier. This approach was used to not only provide additional input into the findings secured from stage two but act as a validation measure to confirm the maturity levels and associated definitions for each of 17 variables. This final process would help confirm the variables' definitions, attainment levels, and measurement indicators across the three maturity levels. In this respect, Level 1 (No Clear Application) presents organisations with issues they need to re-visit regarding their existing operations and any restructuring needed to improve efficiency/readiness. Level 2 (Frequent Application, but Lack of Standard Practice) highlights the frequency of application lack of policy issues, including the need to significantly repeat and standardise processes in line with clear strategy/policy directions. Finally, Level 3 (Clear Established Practices and Procedures) focuses on the need to establish clear OSC policies. This includes a full evaluation of existing operations with clear project strategies to deliver best practice and document lessons learned (as part of their organisational learning strategy). This includes recording experiences and lessons learned from previous projects and best in class provision offered by other companies.

Findings from stage 3 of this work are presented in the form of an OSC readiness maturity model. This model is divided into four tables, reflecting the three levels and four factors highlighted earlier - specifically: Table 4 (Factor 1); Table 5 (Factor 2); Table 6 (Factor 3) and Table 7 (Factor 4). 
Table 4. Off-site Construction Readiness Maturity Model: Factor 1

\begin{tabular}{|c|c|c|c|}
\hline & Level 1 & Level 2 & Level 3 \\
\hline & No Clear Application & $\begin{array}{c}\text { Frequent Application, but Lack of } \\
\text { Standard Practice }\end{array}$ & $\begin{array}{c}\text { Clear Established Practices and } \\
\text { Procedures }\end{array}$ \\
\hline $\begin{array}{l}\text { Factor 1: } \\
\text { Operational Challenges }\end{array}$ & $\begin{array}{l}\text { Organisation may/may not practice the } \\
\text { critical steps needed for effective } \\
\text { implementation of OSC. Organisations at } \\
\text { this level will need to re- visit existing } \\
\text { operations and/or restructure teams to } \\
\text { improve efficiency/readiness. }\end{array}$ & $\begin{array}{l}\text { Frequency of application. Level of } \\
\text { repletion of a series of critical } \\
\text { techniques. Some scope for improvement } \\
\text { in processes, including the need to define } \\
\text { standard practice. }\end{array}$ & $\begin{array}{l}\text { Clear standard OSC practices. Constant } \\
\text { review of existing operations with clear } \\
\text { project strategies to increase efficiency. } \\
\text { Best practice captured and documented } \\
\text { (lessons learned). }\end{array}$ \\
\hline $\begin{array}{l}\text { F1. 1. Complex Interface between } \\
\text { Systems: Organisational response to } \\
\text { assembly and project complexity. }\end{array}$ & $\begin{array}{c}\text { Workforce awareness of assembly } \\
\text { techniques and interfacing of different } \\
\text { products. }\end{array}$ & $\begin{array}{c}\text { Demonstration of assembly approaches } \\
\text { of new complex structures prior to } \\
\text { erection. }\end{array}$ & $\begin{array}{l}\text { Evidence of learning from one project to } \\
\text { another. Training, support and capacity } \\
\text { building. }\end{array}$ \\
\hline $\begin{array}{l}\text { F1.2. Duties and Taxes: Use and } \\
\text { incorporation. }\end{array}$ & $\begin{array}{l}\text { Identification of duties and taxes with } \\
\text { OSC products. }\end{array}$ & $\begin{array}{l}\text { Viability of OSC material procurement } \\
\text { strategy (home/overseas). Clear records. }\end{array}$ & $\begin{array}{c}\text { Optimisation of home/overseas } \\
\text { liabilities, incentives and exemptions. }\end{array}$ \\
\hline $\begin{array}{l}\text { F1.3. Level of OSC Experience: } \\
\text { Previous projects and level of } \\
\text { expertise. }\end{array}$ & $\begin{array}{l}\text { Design/project development teams' } \\
\text { awareness of OSC practices? }\end{array}$ & $\begin{array}{l}\text { Senior management, project teams, and } \\
\text { construction workforce experience. }\end{array}$ & $\begin{array}{l}\text { Dedicated project teams and workforce } \\
\text { specialised in OSC. }\end{array}$ \\
\hline $\begin{array}{l}\text { F1.4. Promoting OSC Advantages: } \\
\text { Image and reputation. Key selling } \\
\text { points. }\end{array}$ & $\begin{array}{l}\text { Promotion of OSC potential benefits. } \\
\text { Use of enlightenment programs to clarify } \\
\text { concerns. }\end{array}$ & $\begin{array}{l}\text { Awareness workshops? Client briefing } \\
\text { on OSC methods and achievable benefits } \\
\text { prior to construction. }\end{array}$ & $\begin{array}{l}\text { Active promotion of OSC benefits. } \\
\text { Showcase of previous projects, value } \\
\text { proposition. Strategic engagement. }\end{array}$ \\
\hline $\begin{array}{l}\text { F1.5. Lead Times: Capability of } \\
\text { organisation to address delays caused } \\
\text { by long lead times? }\end{array}$ & $\begin{array}{l}\text { Prior consultation with manufacturers } \\
\text { before finalising critical events in the } \\
\text { project schedule. }\end{array}$ & $\begin{array}{c}\text { Clear planning aligned to delivery } \\
\text { schedules to avoid time lags and delays. }\end{array}$ & $\begin{array}{l}\text { Full integration with manufacturers and } \\
\text { supply chain partners. Dynamic } \\
\text { collaboration of events. }\end{array}$ \\
\hline $\begin{array}{l}\text { F1.6. Client Resistance/Scepticism: } \\
\text { Organisation's ability to address these } \\
\text { issues. }\end{array}$ & Explanation of potential OSC benefits. & $\begin{array}{l}\text { Clear client reassurement measures } \\
\text { highlighting advantages, estimates and } \\
\text { supportive documentation. }\end{array}$ & $\begin{array}{l}\text { Direct client engagement in key decision } \\
\text { making process. Showcase of successful } \\
\text { projects as exemplars. }\end{array}$ \\
\hline $\begin{array}{l}\text { F1.7. Guidance and Information: } \\
\text { Staff guidance and information on } \\
\text { OSC. }\end{array}$ & $\begin{array}{l}\text { Workforce guidance and availability of } \\
\text { OSC material, training, technical } \\
\text { manuals, new products literature etc. }\end{array}$ & $\begin{array}{l}\text { Provision of OSC workshops and } \\
\text { dedicated training prior to project } \\
\text { implementation. }\end{array}$ & $\begin{array}{l}\text { Availability of dedicated resources } \\
\text { (instructor, technical team, library, } \\
\text { training room, facilities etc.) to enable } \\
\text { training/guidance (office/and on site). }\end{array}$ \\
\hline
\end{tabular}




\begin{tabular}{|c|c|c|c|}
\hline & & & \\
\hline & Level 1 & Level 2 & Level 3 \\
\hline & No Clear Application & $\begin{array}{l}\text { Frequent Application, but Lack of } \\
\text { Standard Practice }\end{array}$ & $\begin{array}{c}\text { Clear Established Practices and } \\
\text { Procedures }\end{array}$ \\
\hline $\begin{array}{c}\text { Factor 2: } \\
\text { Broad Execution Strategy }\end{array}$ & $\begin{array}{l}\text { Organisation may/may not practice the } \\
\text { critical steps needed for effective } \\
\text { implementation of OSC. Organisations at } \\
\text { this level will need to re- visit existing } \\
\text { operations and/or restructure teams to } \\
\text { improve efficiency/readiness. }\end{array}$ & $\begin{array}{l}\text { Frequency of application. Level of } \\
\text { repletion of a series of critical } \\
\text { techniques. Some scope for improvement } \\
\text { in processes, including the need to define } \\
\text { standard practice. }\end{array}$ & $\begin{array}{l}\text { Clear standard OSC practices. Constant } \\
\text { review of existing operations with clear } \\
\text { project strategies to increase efficiency. } \\
\text { Best practice captured and documented } \\
\text { (lessons learned). }\end{array}$ \\
\hline $\begin{array}{l}\text { F2.1. Transportation infrastructure: } \\
\text { Plans and arrangements made to } \\
\text { address transportation network issues. }\end{array}$ & $\begin{array}{c}\text { Awareness of the minimum requirements } \\
\text { to transport materials used in OSC } \\
\text { projects. }\end{array}$ & $\begin{array}{c}\text { Prior evaluation strategies of existing } \\
\text { road and transportation network, } \\
\text { including customised procurement } \\
\text { strategies. }\end{array}$ & $\begin{array}{l}\text { Early stage coordination with } \\
\text { manufacturers to document route plan } \\
\text { and schedules before placing orders }\end{array}$ \\
\hline $\begin{array}{l}\text { F2.2. Manufacturing Facility: } \\
\text { Material handling capability. }\end{array}$ & $\begin{array}{l}\text { Prior consultation with manufacturing } \\
\text { facility to determine material, quantities } \\
\text { and handling requirements. }\end{array}$ & $\begin{array}{l}\text { Early stage engagement with } \\
\text { manufacturing facility to procure orders } \\
\text { and establish planning arrangements. }\end{array}$ & $\begin{array}{l}\text { Prior evaluation of manufacturing } \\
\text { capacity and contingency arrangements. } \\
\text { Provision of supply chain agreements. }\end{array}$ \\
\hline $\begin{array}{l}\text { F2.3. Shortages and Availability: } \\
\text { Systems for managing OSC shortages } \\
\text { and availability. }\end{array}$ & $\begin{array}{c}\text { Capability of systems for managing OSC } \\
\text { shortages and availability. }\end{array}$ & $\begin{array}{l}\text { Use of local and imported manufactured } \\
\text { products to meet capacity. }\end{array}$ & $\begin{array}{l}\text { Use/availability of in-house facilities or } \\
\text { collaboration with external } \\
\text { manufacturers to maximise technology } \\
\text { transfer. }\end{array}$ \\
\hline $\begin{array}{l}\text { F2.4. Availability of } \\
\text { Codes/Standards: Provision of } \\
\text { guidelines to designers, operators and } \\
\text { construction workforce. }\end{array}$ & $\begin{array}{c}\text { Access and availability of written } \\
\text { standards/guidelines to project team } \\
\text { members. }\end{array}$ & $\begin{array}{l}\text { Compliance with standards/codes } \\
\text { throughout the design and construction } \\
\text { stages. }\end{array}$ & $\begin{array}{l}\text { Provision of document management } \\
\text { systems to monitor compliance with } \\
\text { standards/codes. }\end{array}$ \\
\hline $\begin{array}{l}\text { F2.5. Maximising Environmental } \\
\text { Lifecycle Performance: Strategies } \\
\text { deployed to maximise sustainable } \\
\text { products and processes. }\end{array}$ & $\begin{array}{l}\text { Awareness of OSC sustainability. } \\
\text { Strategies for prioritising sustainable } \\
\text { products. }\end{array}$ & $\begin{array}{l}\text { Prior engagement of environmental } \\
\text { lifecycle performance analysis at the } \\
\text { beginning of a project. }\end{array}$ & $\begin{array}{l}\text { Policies for using only certified or } \\
\text { approved sustainable products. } \\
\text { Registration for sustainable building } \\
\text { certification. }\end{array}$ \\
\hline $\begin{array}{l}\text { F2.6. Capital Cost: Financial } \\
\text { preparedness and capital investment } \\
\text { resources. }\end{array}$ & $\begin{array}{c}\text { Provision and allocation of dedicated } \\
\text { funds to support and accelerate the } \\
\text { adoption of OSC. }\end{array}$ & $\begin{array}{l}\text { Bespoke financial strategy for leveraging } \\
\text { future OSC investments. }\end{array}$ & $\begin{array}{l}\text { Investment policies and diversification } \\
\text { strategies. Critical evaluation of business } \\
\text { patterns and investment strategies. }\end{array}$ \\
\hline
\end{tabular}


Table 6. Off-site Construction Readiness Maturity Model: Factor 3

\begin{tabular}{|c|c|c|c|}
\hline & Level 1 & Level 2 & Level 3 \\
\hline & No Clear Application & $\begin{array}{c}\text { Frequent Application, but Lack of } \\
\text { Standard Practice }\end{array}$ & $\begin{array}{l}\text { Clear Established Practices and } \\
\text { Procedures }\end{array}$ \\
\hline $\begin{array}{l}\text { Factor 3: } \\
\text { Planning Certainty }\end{array}$ & $\begin{array}{l}\text { Organisation may/may not practice the } \\
\text { critical steps needed for effective } \\
\text { implementation of OSC. Organisations at } \\
\text { this level will need to re- visit existing } \\
\text { operations and/or restructure teams to } \\
\text { improve efficiency/readiness. }\end{array}$ & $\begin{array}{l}\text { Frequency of application. Level of } \\
\text { repletion of a series of critical } \\
\text { techniques. Some scope for improvement } \\
\text { in processes, including the need to define } \\
\text { standard practice. }\end{array}$ & $\begin{array}{c}\text { Clear standard OSC practices. Constant } \\
\text { review of existing operations with clear } \\
\text { project strategies to increase efficiency. } \\
\text { Best practice captured and documented } \\
\text { (lessons learned). }\end{array}$ \\
\hline $\begin{array}{l}\text { F3.1. Cost Certainty: Extent to which } \\
\text { the organisation plans and monitors } \\
\text { budget performance. }\end{array}$ & $\begin{array}{l}\text { Early documentation of cost estimates. } \\
\text { Evidence of integration between project } \\
\text { administration and control. }\end{array}$ & $\begin{array}{l}\text { Availability and use of resource } \\
\text { monitoring and evaluation. Variance } \\
\text { analysis systems and procedures. }\end{array}$ & $\begin{array}{c}\text { Strategic use of standardised project } \\
\text { financial accounting and management } \\
\text { systems. }\end{array}$ \\
\hline $\begin{array}{l}\text { F3.2. Time Certainty: Planning of } \\
\text { critical activities to match } \\
\text { organisational capability and delivery } \\
\text { requirements. }\end{array}$ & $\begin{array}{l}\text { Early identification of critical activities } \\
\text { and associated sequences to predict time } \\
\text { certainty. }\end{array}$ & $\begin{array}{l}\text { Application, monitoring and review } \\
\text { systems to evaluate on-site activities. } \\
\text { Delay mitigation strategies. }\end{array}$ & $\begin{array}{c}\text { Engagement of policies and procedures } \\
\text { to standardise/optimise process } \\
\text { performance. }\end{array}$ \\
\hline
\end{tabular}


Table 7. Off-site Construction Readiness Maturity Model: Factor 4

\begin{tabular}{|c|c|c|c|}
\hline & Level 1 & Level 2 & Level 3 \\
\hline & No Clear Application & $\begin{array}{l}\text { Frequent Application, but Lack of } \\
\text { Standard Practice }\end{array}$ & $\begin{array}{c}\text { Clear Established Practices and } \\
\text { Procedures }\end{array}$ \\
\hline $\begin{array}{c}\text { Factor 4: } \\
\text { Operational Efficiency }\end{array}$ & $\begin{array}{l}\text { Organisation may/may not practice the } \\
\text { critical steps needed for effective } \\
\text { implementation of OSC. Organisations at } \\
\text { this level will need to re- visit existing } \\
\text { operations and/or restructure teams to } \\
\text { improve efficiency/readiness. }\end{array}$ & $\begin{array}{l}\text { Frequency of application. Level of } \\
\text { repletion of a series of critical } \\
\text { techniques. Some scope for improvement } \\
\text { in processes, including the need to define } \\
\text { standard practice. }\end{array}$ & $\begin{array}{l}\text { Clear standard OSC practices. Constant } \\
\text { review of existing operations with clear } \\
\text { project strategies to increase efficiency. } \\
\text { Best practice captured and documented } \\
\text { (lessons learned). }\end{array}$ \\
\hline $\begin{array}{l}\text { F4.1. Minimising On-Site Duration: } \\
\text { Capability of the organisation to } \\
\text { reduce/minimise the duration of non- } \\
\text { critical construction activities on site. }\end{array}$ & $\begin{array}{c}\text { Identification and control measures to } \\
\text { minimise/reduce non-critical } \\
\text { construction activities during planning } \\
\text { and on site? }\end{array}$ & $\begin{array}{l}\text { Use and application of planning systems } \\
\text { to execute parallel activities during } \\
\text { planning and on site. }\end{array}$ & $\begin{array}{l}\text { Systems for ensuring OSC activities are } \\
\text { completed before commencement on site. } \\
\text { Application of standardised on-site } \\
\text { working process. }\end{array}$ \\
\hline $\begin{array}{l}\text { F4.2. Prompt Delivery: } \\
\text { Organisational ability to ensure prompt } \\
\text { delivery of products and services. }\end{array}$ & $\begin{array}{c}\text { Early engagement with supply chain } \\
\text { partners to maximise logistics } \\
\text { arrangements. }\end{array}$ & $\begin{array}{l}\text { Liaison and integration with vendors, } \\
\text { consultants and supply chain partners to } \\
\text { optimise synergy. }\end{array}$ & $\begin{array}{l}\text { Use of performance monitoring systems. } \\
\text { Directory of partnering arrangements, } \\
\text { service/vendor provider performance. }\end{array}$ \\
\hline
\end{tabular}




\section{Discussion}

The OSC readiness maturity model presented in Tables 4, 5, 6 and 7 presents a new approach for evaluating Indian construction organisations ability and readiness to enter the off-site market. However, acknowledging that there are no currently accepted definitions for readiness per se (Lou et al., 2012), the term readiness (in the context of this paper) relates to the position to which an organisation aspires to be ready, prepared and willing to leverage benefits from OSC. Given the rationale for developing this OSC readiness maturity model, and the need to provide organisations with a structured approach for evaluating People, Process and Technology (Goulding and Arif, 2013); the primary aim of this model was to provide a vehicle for matching capability with need. Specifically, an opportunity for organisations to assess their current readiness, along with improvement measures needed to achieve optimum OSC benefits.

Results from this study highlighted the need to evaluate 17 variables across four factors and three maturity levels. The four factors (Table 3), provided a vehicle for mapping these 17 variables against. The first factor (Factor 1: Operational Challenges) considered the challenges of OSC, which presents indicators needed to assess the readiness of an organisation to address these challenges. Effective performance of this factor was seen as a core indicator for successful OSC uptake. One of the essential variables here is the complex interface needed between systems. The connections between various systems and individual products involved in OSC processes are complex, requiring special attention from all stakeholders. This includes everyone from procurement, through to design, assembly and construction. This also naturally embraces the need to embrace training and development as part of this process. Another issue to address is the need to understand duties and taxes, including excise and customs levies placed on systems or components either manufactured in the country or imported from foreign countries. This also includes taxes payable at various points during the construction processthe variable "F1.3. Level of OSC Experience" highlights the level of experience needed to OSC demands, which was seen as a major contributor to the success of OSC initiatives. Other important issues to raise in the first factor was the need to address the perceived negative issue often associated with OSC. Whist this to some extent is related to cultural norms and perceptions (Nadim and Goulding, 2011; Arif et al., 2012 a), this is something that needs to be addressed from the outset in order promote uptake in India. Another important issue to raise here relates to the extended lead-in periods that tend to accompany OSC. This can have a significant impact on the organisation apropos it's the capability of dealing with delays between initiation and execution of processes. This can also have an impact on client acceptance, as clients sometimes exhibit resistance to new concepts and ideas (such as OSC). The final variable in Factor 1 "F1.7. Guidance and Information" highlight the need to provide support and guidance information on OSC methods. This includes a basic provision, through to dedicated resources (instructor, technical team, library, training room, facilities, etc.) to facilitate fulling integrated support (office/and on-site).

Findings presented in Factor 2 (Factor 2: Broad Execution Strategy) provides the strategic indicators needed for successful OSC delivery. This includes the effective application of performance indicators needed to deliver the strategy. Where, for example, the transportation infrastructure indicator describes the planning and coordination of transporting various off-site 
systems, including logistics and infrastructure transportation planning. Manufacturing capacity deals with issues such as product volume (generated by a production plant, manufacturing facility or company) within the available timescale. This also examines the organisation's planning and utilisation of manufacturing facilities. The local availability variable (F2.3. Shortages and Availability) focuses on the utilisation of OSC products available locally, including indicators to address shortfalls. The codes and standards variable deals with the set of technical guidelines that function as instructions for designers, operators and other construction workforce members dealing with OSC practices within the organisation. This indicator helps ensure OSC activities comply with required standards and also helps to protect clients. The environmental impact variable (F2.5. Maximising Environmental Lifecycle Performance) evaluates the impact of various construction activities (e.g. site preparation, materials and equipment, etc.) on the environment. This also highlights other issues such as noise pollution, sustainability, landfill, re-use etc. (Jaillon et al., 2009; Arif et al., 2012b; Krug, 2013; Gong et al., 2019; Jin et al., 2020). The final variable on cost (F2.6. Capital Cost) deals with the strategies and financial preparedness of the organisation in terms of its OSC capital investment.

Findings presented in Factor 3 (Factor 3: Planning Certainty) investigates the level of efficiency achieved by the organisation through planning various activities and cost schedules in order to enable optimal use of different OSC techniques. Where, for example, the cost certainty variable (F3.1. Cost Certainty) stresses the importance of planning, monitoring, and controlling costs at all stages - from inception through to delivery and handover. This is an important indicator to ensure cost certainty. The use of variance analysis is seen as an important tool in this process. Similarly, the time certainty variable (F3.2. Time Certainty) emphasises the effective use of time planning and the scheduling of various OSC activities. This indicator evaluates the methods adopted by the organisations in terms of time planning to maximise time certainty in accordance with agreed delivery dates.

The fourth and final factor (Factor 4: Operational Efficiency) focuses on operational indicators that impinge on OSC success. This includes indicators that measure the impact of OSC - from planning through to implementation and post-project review. Where, for example, the on-site variable (F4.1. Minimising On-Site Duration) incorporates indicators for managing effective coordination and execution of various activities during planning and construction. This is supported by the speed of delivery indicator (F4.2. Prompt Delivery) which evaluates systems and processes to ensure products and services are properly planned and delivered to enable smooth project flow. This includes the provision of clear communication and integration streams with vendors, consultants and supply chain partners to optimise synergy.

In summary, the four-factor Offsite Construction Readiness Maturity Model presents the Indian construction industry with an OSC readiness maturity model to apply, enhance and optimise OSC techniques and strategies. The main advantages of this model are as follows: 
- Accelerates the effective implementation of OSC methods within construction organisations.

- Enables organisations to evaluate and benchmark their processes throughout all strategic, operational phases.

- Provides organisations with insight and scope to develop appropriate strategies for the successful implementation of OSC methods.

- Enables organisations to identify areas which require improvement or change.

\section{Conclusion}

This paper presented a discussion on the OSC market, focussing specifically on the challenges and opportunities for construction organisations operating in the Indian construction sector. In doing so, it outlined the research methodological approach adopted for developing an OSC readiness maturity model for assessing the readiness of off-site construction stakeholders within this sector. This included three stages; where: stage 1 presented findings from the literature, highlighting 17 unique variables affecting OSC adoption in India. Stage two presented findings from 15 semi-structured interviews, which refined these variables (within the Indian context) and established the different levels of attainment required for each variable. The final stage (Stage 3) employed the expertise of five domain experts to test and validate findings and definitions mapped against each of the maturity levels.

Findings were articulated through an "Offsite Construction Readiness Maturity Model”, which identified four core factors (F1: Operational Challenges, F2: Broad Execution Strategy, F3: Certainty in Planning, and F4: Operational Efficiency), all of which were mapped against 17 variables spanning three levels of maturity. The appropriation of maturity levels provides clear guidance and direction into the practical stages and issues needed for construction entities to maximise their OSC engagement within the Indian market. This also provides suitable direction and measures for evaluating and benchmarking their processes (strategic and operational) against core phases. The corollary of which enables organisations to evaluate their OSC 'preparedness' or readiness for engaging in the OSC market. This maturity readiness model also serves as a guide to support concomitant services such as supply chain partners, policy directives, manufacturing provision etc. Whilst it is accepted that this model is primarily predicated and designed to meet the needs of the Indian OSC community, the homogeneity of this model is such that it could be adapted to suit other OSC markets and contexts. Ongoing work is, therefore needed to support construct reliability and repeatability.

\section{Acknowledgements}

The authors would like to personally thank all participants for their engagement, support and insight used in the development of this Offsite Construction Readiness Maturity Model. 


\section{References}

Aldridge, G., Pasquire, C., Gibb, A. and Blismas, N., (2001), METHODS FOR MEASURING THE "UNMEASURABLE": EVALUATING THE BENEFITS OF PRE-ASSEMBLY AND STANDARDISATION IN CONSTRUCTION. In 17th Annual ARCOM Conference, 5-7 September 2001, University of Salford. Association of Researchers in Construction Management Vol. 1, pp. 311319.

Antoine, A. L. C., Alleman, D. and Molenaar, K. R. (2018) 'Examination of Project Duration, Project Intensity, and Timing of Cost Certainty in Highway Project Delivery Methods', Journal of Management in Engineering, 35(1), p. 04018049. doi: 10.1061/(ASCE)me.1943-5479.0000661.

Arif, M., Bendi, D., Sawhney, A, and Iyer, K.C., (2012)a , State of off-site construction in India-Drivers and barriers, Journal of Physics: Conference Series, 364 012109, IOP Publishing Ltd, http://dx.doi.org/10.1088/1742-6596/364/1/012109

Arif, M., Bendi, D., Toma-Sabbagh, T. and Sutrisna, M. (2012) $)^{\mathrm{b}}$, Construction waste management in India: an exploratory study, Construction Innovation, Vol. 12 No. 2, pp. 133-155. https://doi.org/10.1108/14714171211215912

Ayinla, K.O., Cheung, F. and Tawil, A.-R. (2019), “Demystifying the concept of off-site manufacturing method: Towards a robust definition and classification system”, Construction Innovation, Vol. 20 No. 2, pp. 223-246. https://doi.org/10.1108/CI-07-2019-0064

Bekdik, B., Pörzgen, J., Bull, S.S. and Thuesen, C., (2018), Modularising design processes of façades in Denmark: re-exploring the use of design structure matrix. Architectural Engineering and Design Management, 14(1-2), pp. 95-108.

Bendi, D. (2017) Developing an off-site readiness framework for Indian construction organisations, $P h D$ Thesis. University of Salford Archive. Available at: http://usir.salford.ac.uk/id/eprint/42599/

Bendi, D., Rana, M.Q., Arif, M., Goulding, J.S. and Kaushik, A.K. (2020), understanding off-site readiness in Indian construction organisations, Construction Innovation, Vol. ahead-of-print No. aheadof-print. https://doi.org/10.1108/CI-02-2020-0016

Blismas, N and Wakefield, R (2008), Off-site manufacture in Australia: barriers and opportunities, 1214 March, 2008, Gold Coast, Australia, QUT Digital Repository, https://eprints.qut.edu.au/27182/1/27182.pdf

Blismas, N. and Wakefield, R. (2009), Drivers, constraints and the future of off-site manufacture in Australia, Construction Innovation, 9(1), pp. 72-83. https://doi.org/10.1108/14714170910931552

Blismas, N., Pasquire, C. and Gibb, A. (2006), Benefit evaluation for off-site production in construction, Construction Management and Economics, 24:2, 121-130, https://doi.org/10.1080/01446190500184444

Bowmaster, J., and Rankin, J., (2019), A Research Roadmap for Offsite Construction: Automation and Robotics, Proceedings of the 2019 Modular and Off-site Construction (MOC) Summit, Banff, Alberta, Canada, May 21 - 24, 2019, https://doi.org/10.29173/mocs91

BURA, (2005), Modern methods of construction: Evolution or revolution? British Urban Regeneration Association, BURA Steering and Development Forum Report, London. https://www.thenbs.com/PublicationIndex/documents/details?Pub=BURA\&DocID=276735

Bryman, A. and Bell, E. (2015) Business Research Methods. $4^{\text {th }}$ Ed., Oxford University Press, ISBN- 
BRE, (2001) Current practice and potential uses of prefabrication, Project report number 203032, Building Research Establishment Watford, UK., https://projects.bre.co.uk/prefabrication/prefabrication.pdf

CITB (2017) Faster, Smarter, More Efficient: Building Skills for Offsite Construction. Available at: https://www.citb.co.uk/documents/research/offsite_construction/offsite_construction_full_report_201 70410.pdf (Accessed: 7 May 2019).

CRC (Cooperative Research Centre for Construction Innovation)., 2007. Off-site manufacture in Australia: Current state and future directions. Cooperative Research Centre for Construction Innovation.

Creswell, J.W. (2007). Qualitative inquiry and research design: Choosing among five approaches (2nd ed.) California, USA: Sage Publications, Inc. ISBN: 978-1412995306

Davis, P.R. and Walker, D.H.T., 2009. Building capability in construction projects: a relationship-based approach. Engineering, Construction and Architectural Management.

Davis, P.R. and Walker, D.H.T. (2009), "Building capability in construction projects: a relationshipbased approach”, Engineering, Construction and Architectural Management, Vol. 16 No. 5, pp. 475489. https://doi.org/10.1108/09699980910988375

Eadie, R., Perera, S. and Heaney, G. (2011), "Key process area mapping in the production of an ecapability maturity model for U.K. construction organisations”, Journal of Financial Management of Property and Construction, Vol. 16 No. 3, pp. 197-210. https://doi.org/10.1108/13664381111179198

Edialeyoung, B., Seidu, R. D. and Appiah-kubi, J. (2020) 'Modular Construction Innovation in the U.K. : The Case of Residential Buildings', Proceedings of the International Conference on Industrial Engineering and Operations Management, 2022, pp. 806-816.

El-Abidi, K.M.A., Ofori, G., Zakaria, S.A.S. and Aziz, A.R.A., 2019. Using Prefabricated Building to Address Housing Needs in Libya: A Study based on Local Expert Perspectives. Arabian Journal for Science and Engineering, 44(10), pp.8289-8304.

Fellows, R.F, and Liu, A.M.M. (2015), Research methods for construction, Chichester, UK: John Wiley and Sons Ltd. ISBN 978-1-118-91574-5

Fergusson, H. and Langford, D.A., 2006. Strategies for managing environmental issues in construction organisations. Engineering, Construction and Architectural Management.

Finnemore, M. and Sarshar, M. (2000) 'Benchmarking and readiness assessment for concurrent engineering in construction (BEACON)', in Bizarre Fruit 2000 Conference. University of Salford (pp. 9-10).

Gong, P., Teng, Y., Li, X., and Luo, L., (2019), Modeling Constraints for the On-Site Assembly Process of Prefabrication Housing Production: A Social Network Analysis, Sustainability 2019, 11, 1387. https://doi.org/10.3390/su11051387

Goodier and Gibb (2005) 'Barriers and Opportunities for Offsite in the U.K.', Abdul Samed Kazi,ed. Systematic Innovation in the Management of Project and Processes, 11th Joint CIB International Symposium, 13-16 June 2005, pp. 148-158.

Goodier, C. and Gibb, A., 2007. Future opportunities for off-site in the U.K. Construction Management and Economics, 25(6), pp.585-595. 
Goulding J.S, and Alshawi M, (2002), Generic and Specific I.T. Training: A Process Protocol Model for Construction, Journal of Construction Management and Economics, Vol. 20, No. 6, pp. 493-505 https://doi.org/10.1080/01446190210151069

Goulding, J. and Arif, M. (2013) Offsite Production and Manufacturing, CIB General Secretariat. Available at: https://site.cibworld.nl/dl/publications/pub_372.pdf.

Goulding, J.S., Pour Rahimian, F., Arif, M., and, Sharp, M., (2015), New Offsite Production and Business Models in Construction: Priorities for the Future Research Agenda, Journal of Architectural Engineering and Design Management, Vol. 11, Iss 3, pp 163-184, 2015 http://dx.doi.org/10.1080/17452007.2014.891501

Goulding, J.S., Pour Rahimian, F, Arif, M., and Sharp., M.D., (2012), Off-site Construction: Strategic Priorities for Shaping the Future Research Agenda, Journal of Architectoni.ca, Vol. 1, No.1., pp. 62-73, DOI:10.5618/arch.2012.v1.n1.7 http://www.ccaasmag.org/arch_2012/vol1/Rahimian_offsiteconstruction.pdf

Goulding J.S, and Alshawi M, (2002), Generic and Specific I.T. Training: A Process Protocol Model for Construction, Journal of Construction Management and Economics, Vol. 20, No. 6, pp 493-505 https://doi.org/10.1080/01446190210151069

Gupta, R., Jambunatahan, S., and Netzer, T., (2009) Building India: Accelerating Infrastructure Projects. McKinsey \& Company, Available at: https://www.mckinsey.com/ /media/mckinsey/industries/travel\%20transport\%20and\%20logistics/our \%20insights/transforming\%20indias\%20logistics\%20infrastructure/building_india\%20transforming_t he nations logistics infrastructure.ashx (Accessed: 7 June 2020).

Hartmann, A. and Hietbrink, M., 2013. An exploratory study on the relationship between stakeholder expectations, experiences and satisfaction in road maintenance. Construction management and economics, 31(4), pp.345-358.

Hinks, A. J., Aouad, R., Cooper, D., Sheath, D., Kagioglou, M., and Sexton, M. (1997). I.T. and the Design and Construction Process: A Conceptual Model of Co-maturation. International Journal of Construction Information Technology, 5(1), pp. 1-25.

Hinks, J. (1998) 'A conceptual model for the interrelationship between information technology and facilities management process capability’, Facilities. doi: 10.1108/02632779810229057.

Holt, G.D., and Goulding, J.S. (2017). The essential 'Ological-triad': considerations for construction management research, Journal of Engineering, Design and Technology. 15(3), pp. 286-304. http://dx.doi.org/10.1108/JEDT-03-2016-0019

Hyde, K.F. (2000), Recognising deductive processes in qualitative research, Qualitative Market Research, Vol. 3 No. 2, pp. 82-90. https://doi.org/10.1108/13522750010322089

IMMPREST (2007) IMMPREST (Interactive Method for Measuring PRE-assembly and STandardization benefit in construction) by Loughborough University ). Available at: https://immprest.lboro.ac.uk/ www.IMMPREST.com.

Innovate Offsite (2010) 'Aguide to off-site and howit is being made to work today', Innovate Offsite Magazine, Mtech Consult.

Jaillon, L. and Poon, C.S., 2010. Design issues of using prefabrication in Hong Kong building construction. Construction Management and Economics, 28(10), pp.1025-1042. 
Jaillon, L., Poon, C. S. and Chiang, Y. H. (2009) 'Quantifying the waste reduction potential of using prefabrication in building construction in Hong Kong’, Waste Management. Elsevier Ltd, 29(1), pp. 309-320. doi: 10.1016/j.wasman.2008.02.015.

Jin, R., Hong, J. and Zuo, J., 2020. Environmental performance of off-site constructed facilities: A critical review. Energy and Buildings, 207, p.109567.

Kamar, K.A.M., Alshawi, M. and Hamid, Z., 2009, January. Barriers to industrialised building system (IBS): The case of Malaysia. In BuHu 9th international postgraduate research conference (IPGRC) (pp. 45-55). Salford, United Kingdom.

Karningsih, P.D., Anggrahini, D. and Syafi'i, M.I., 2015. Concurrent engineering implementation assessment: a case study in an Indonesian manufacturing company. Procedia Manufacturing, 4, pp.200-207.

Kenneth, F. H. (2000). Recognising deductive processes in qualitative research. Qualitative Market Research: An International Journal.

Khalfan, M.M., Anumba, C.J. and Carrillo, P.M., 2001. Development of a readiness assessment model for concurrent engineering in construction. Benchmarking: An International Journal.

Krug, D. (2013) OFF-SITE CONSTRUCTION: Sustainability Characteristics. Available at: https://www.buildoffsite.com/content/uploads/2015/03/BoS_offsiteconstruction_1307091.pdf

(Accessed: 7 June 2020).

Kumar, D. D. (2019) 'A system dynamics model of client linked delay in construction of building projects in India', Proceedings, Annual Conference - Canadian Society for Civil Engineering, 2019June.

Kwak, Y.H. and Ibbs, C.W., 2002. Project management process maturity (PM) 2 model. Journal of management in engineering, 18(3), pp.150-155.

Lou., E.C.W., Alshawi, M., and Goulding, J.S., (2012), E-Readiness in Construction, pp. 363-383, in Akintoye, A., Goulding, J.S., and Zawdie, G., (Eds.), Construction Innovation and Process Improvement, Wiley-Blackwell, U.K., ISBN: 9781405156486

Maniar, H., 2010. risk analysis of infrastructure projects: a case study on build-operate-transfer projects in India. IUP Journal of Financial Risk management, 7(4), p.34.

Mao, C. et al. (2013) 'Major Barriers to Offsite Construction: The Developer's Perspective in China', Journal of Management in Engineering, 31(3), p. 04014043. doi: 10.1061/(asce)me.19435479.0000246 .

Mao, C., Shen, Q., Pan, W., and Ye, K., (2015), Major Barriers to Offsite Construction: The Developer's Perspective in China, Journal of Management in Engineering, Vol. 31, Iss. 3, American Society of Civil Engineers, https://doi.org/10.1061/(ASCE)ME.1943-5479.0000246

Miles, M.B., Huberman, A.M., and Saldaña, J. (2013). Qualitative data analysis: A methods sourcebook. Thousand Oaks, California, U.S.: SAGE Publications. ISBN: 978-1452257877

Nadim, W., and Goulding, J.S., (2010), Offsite Production in the U.K.: The Way Forward?, A UK Construction Industry Perspective, Journal of Construction Innovation, Vol. 10, No. 2., pp. 181-202, 2010, https://doi.org/10.1108/14714171011037183

Nadim, W., and Goulding, J.S., (2011), Offsite Production: A Model for Building Down Barriers: A European Construction Industry Perspective, Journal of Engineering, Construction and Architectural 
Management, Vol. 18, No. 1., pp. 82-101, http://dx.doi.org/10.1108/09699981111098702

Nallathiga, R., Shaikh, H.D., Shaikh, T.F. and Sheik, F.A., 2017. Factors Affecting the Success/Failure of Road Infrastructure Projects Under PPP in India. Journal of Construction Engineering and Project Management, 7(4), pp.1-12.

NITI Aayog (2018) Annual Report 2017-18. New Delhi, India. Available at: https://niti.gov.in/writereaddata/files/document_publication/Annual-Report-English.pdf (Accessed: 8 May 2019).

Oughton, D., (2016), Construction Leadership Council Innovation Workstream (Buildings), Roadmap for Modern Methods of Construction (MMC), Workshop Report Issue 1.0 April 2016, https://baumanlyons.co.uk/wp-content/uploads/2016/05/Roadmap-for-Modern-Methods-ofConstruction1.pdf

Pasquire, C. L., \& Gibb, A. G. (2002) 'Considerations for assessing the benefits of standardisation and pre-assembly in construction.'

Perera, S. et al. (2017) Advances in construction ICT and e-Business, Advances in Construction ICT and e-Business. doi: 10.4324/9781315690698.

Perera, S., \& Rodrigo, A. (2017). Capability maturity modelling of construction e-business processes. In S. Perera, B. Ingirige, K. D. Ruikar, \& E. A. Obonyo (Eds.), Advances in Construction ICT and eBusiness pp. 263-295. https://doi.org/10.4324/9781315690698-12

Rahman, M.M., 2014. Barriers of implementing modern methods of construction. Journal of management in engineering, 30(1), pp.69-77.

Razkenari, M., Fenner, A., Shojaei, A., Hakim, H. and Kibert, C., 2020. Perceptions of off-site construction in the United States: An investigation of current practices. Journal of Building Engineering, 29, p.101138.

Rogers, E.M. (2010). Diffusion of innovations. New York, US.: Simon and Schuster. ISBN: 9781451602470

Sarshar, M., Haigh, R., Finnemore, M., Aouad, G., Barrett, P., Sexton, M., \& Baldry, D. (2000). SPICE: a business process diagnostics tool for construction projects. Engineering, Construction and Architectural Management, 7(3), pp. 241-250. https://doi.org/10.1108/eb021149

Smith, R. and Narayanamurthy, S., 2008, July. Prefabrication in developing countries: a case study of India. In Wood Structures Symposium (p. 5).

Wasim, M., Han, T.M., Huang, H., Madiyev, M. and Ngo, T.D., 2020. An approach for sustainable, cost-effective and optimised material design for the prefabricated non-structural components of residential buildings. Journal of Building Engineering, p.101474.

Wognum, P.M., Stoeten, B.J.B., Kerkhof, M., and de Graff, R. (1996), PMO-RACE: a combined method for assessing organisations for C.E., pp. 113-120, in Advances In Concurrent Engineering: CE96 Proceedings (ed. Prasad). CRC Press, ISBN-13: 978-1566764858

Wood, G., Davis, P., Eadie, R., Perera, S. and Heaney, G., 2011. Key process area mapping in the production of an e-capability maturity model for U.K. construction organisations. Journal of Financial Management of Property and Construction.

WorldBank

(2020)

WorldBank

Stats.

Available

at: 
https://data.worldbank.org/indicator/SP.POP.TOTL?locations=IN.

Wuni, I.Y., Shen, G.Q. and Hwang, B.G., Risks of modular integrated construction: A review and future research directions. Frontiers of Engineering Management, pp.1-18.

Xiao, H. and Proverbs, D. G. (2003), Cost Certainty and Time Certainty: an International Investigation, Association of Researchers in Construction Management, 1 (September), Available at: http://www.arcom.ac.uk/-docs/proceedings/ar2003-023-032_Xiao_and_Proverbs.pdf

Yang, L. R., O’Connor, J. T. and Chen, J. H. (2007) 'Assessment of automation and integration technology's impacts on project stakeholder success', Automation in Construction. doi: 10.1016/j.autcon.2006.11.005. 